\title{
サッカープレーヤーの発達段階および課題の制約としての プレーエリアの大きさがパス技能に与える影響
}

\author{
中山 雅雄 浅井 武
}

Masao Nakayama and Takeshi Asai: Effects of the different stage of development of players and play area size as a task constraint on soccer pass skills. Japan J. Phys. Educ. Hlth sport Sci., 54: 343-353, December, 2009.

\begin{abstract}
The purpose of this study was to investigate the elements that constitute an effective environment for passing practice in soccer by analyzing the relationship between player age range as an organism constraint and the width of the area in which the ball is possessed in a three vs. one (3 vs. 1) task constraint. The task consisted of passing the ball employing one or two touches to maintain possession in a 3 vs. 1 formation in three different square-shaped areas measuring $8 \mathrm{~m} \times 8 \mathrm{~m}, 10 \mathrm{~m} \times 10 \mathrm{~m}$ and $12 \mathrm{~m} \times 12 \mathrm{~m}$. The participants were divided according to age, and categorized as under (U)-10 (fourth grade elementary school), U-12 (sixth grade elementary school), U-14 (second grade junior school) and U-16 (first grade high school). The following criteria were then investigated: passing performance (passing success rate and the number of passing sequences), speed of the passing movement, support available to the player, and decision-making about the passing direction.

It was found that U-10 players performed worse in the task than players in the other age groups. Moreover, passing speed was affected by the width of the play area for the U-10 and U-12 players, but not for the U-14 and U16 players. The distance between the support players was the same for all age groups; however, for the U-10 players, the support angles were more acute than those for the other age groups, thus preventing the U-10 players from adopting useful supporting positions. Furthermore, it was found that the width of the play area did not affect passing performance, but did affect the speed of the passing movement in the 3 vs. 1 task. The distance and the angle of support differed among the players in the different age groups.

It is concluded that a wider area in the 3 vs. 1 possession task creates easier choices for U-10 and U-12 players, leading to easy understanding of the passing motions. For the U-14 and U-16 players, making the area narrower is effective for maintaining a higher 3 vs.1 possession level. From these perspectives, considering the width of the area for 3 vs. 1 possession is important in relation to the developmental stage of soccer players.
\end{abstract}

Key words : 3 vs. 1 practice, training, technique, support

キーワード : 3 vs. 1, 練習, 技術, サポート

\section{1 緒言}

技能の習得に関して，生体，環境，課題といっ た制約（constraint）からの検討が近年なされてき ている (Davids et al, 2008).この中の生体の制約 には，身長や体重などの構造的制約と，脳におけ るシナプス結合の強さや, 認知, 動機, 感情と いった機能的制約とがある。また, 環境の制約に
は自然の中にある重力や温度，運動をする中での 音や光などがあり, 課題の制約にはその課題の目 標や，課題に含まれるルールなどがある（Newell, 1986）。つまり，個人の生体的特性を踏まえ，環境 をデザインし, 課題を工夫することによって, 学 習者が意識することなく意図する動きを引き出し, 技能を習得することができると考えられている.

スポーツに打ける代表的な技能の一つである サッカーに関しても同様に，コーチが練習課題の
筑波大学大学院人間総合科学研究科

干 305-8574 茨城県つくば市天王台 1-1-1 連絡先 中山雅雄
Graduate School of Comprehensive Human Sciences, University of Tsukuba

1-1-1 Tennohdai, Tsukuba, Ibaraki, 305-8574

Corresponding authornnakayama@taiiku.tsukuba.ac.jp 
制約を操作したり，生体や環境の制約を考慮した りすることによって，コーチが求めているプレー を，プレーヤーが指示されながらではなく，プレー ヤー自身で見つけだしながら学ぶ練習過程やゲー 厶状況を作り出すことが奨励されている (Williams, 2003; 中山，2004).この中の課題の制 約については実証的な研究も行われており, Araújo et al.（2005）はサッカーボールの質の違い によるボールコントロール技術の学習の効果を検 討した。その結果，初級者では大きいサイズであ まり弾まないフットサルボールを使うことが有効 であることが示唆されたが，技能レベルとの関連 についてさらに検討する必要があるとしている。 また，中山ほか（2007）はパスを相手に奪われな いようにという練習課題の制約がパスを受ける前 の肩の向きに影響し，初心者が熟練のサッカープ レーヤーと類似した動作を行うようになることを 報告している。このようにサッカーのコーチにとっ て課題の制約を操作することは効果的な技能獲得 のための指導を行う上で有効な手段になり得ると いえる。

ところで，サッカーの重要な技能の一つである パス技能を修得していくための練習課題として, ボール保持課題がある（多和ほか，1978, pp. 158159; Luxbacher, 1991). このボール保持課題に内在 する制約で，コーチが操作できる主要なものとし てエリアの大きさが挙げられる。たとえば， Luxbacher（1991）は 3 対 1 ボール保持課題で難度 を下げるためにエリアを大きくし，難度を上げる ためにエリアを狭くするといった手順を紹介して いる。また，Nakayama（2008）は 11１2 歳のサッ カープレーヤーの 3 対 1 ボール保持課題でのパス 技能の発揮のされ方に $8 \mathrm{~m}, 10 \mathrm{~m}, 12 \mathrm{~m}$ 四方での各 エリアで特徴があることを示しており，エリアの 大きさがそこで発揮されるパス技能に影響を及ぼ していることを実証的に示している。このように， エリアの大きさはコーチが容易に操作することが できると同時に，その大きさはプレーの様相に大 きく影響する制約であることが予測されるが，そ の詳細は明らかではない。

さらに，練習課題を適切に設定するためには，
それに取り組むプレーヤーたちの発育発達やサッ カーの経験年数, 技能レベル，運動能力などサッ カープレーヤーとしての発達段階が考慮されなけ ればならない。多和ほか（1978, p. 358）は，「‥指 導するプレーヤーの能力に応じた適切な指導内容 と指導段階が準備されなければならない」とし， 効果的に指導するためには，身体的・精神的発達 とサッカーの技能の発達過程を考慮することが不 可欠であると指摘している。しかし，プレーヤー としての発達段階に応じた適切な練習課題の設定 についての実証的な研究は見当たらない.

そこで本研究では，サッカープレーヤーとして の発達段階が異なる男子プレーヤーを対象に，3 対 1 ボール保持課題（以下， 3 vs. 1 とする）で, 生体の制約であるサッカープレーヤーとしての発 達段階と，課題の制約であるエリアの大きさがパ ス技能発揮の様相に与える影響を明らかにし，よ り効果的なパス技能の練習環境を探索的に検討す ることを目的にする。

\section{2 方法}

\section{1. サッカープレーヤーとしての発達段階}

プレーヤーとしての発達段階に関しては, サッ カーの多くの指導現場では年齢での区分によって 発達段階をとらえている。たとえば，財団法人日 本サッカー協会技術委員会（2003a，2003b，2003c， 2004, 2007a, 2007b）は，6歳から 16 歳までの指導 指針を 2 歳ごとに発行している。同様に，諸外国 におけるサッカーの指導書においても，年齢での 区分による発達段階に応じた練習課題が示されて いる（Wade, 1978; Van Lingen, 1997）。しかながら, サッカープレーヤーとしての発達段階を年齢によっ て区分した場合には，同じ年齢区分でも個々の サッカー経験, 体力, 運動能力, 認知能力などが 当然異なってくることも考えられる.

他方，サッカープレーヤーとしての発達を技能 獲得の過程ととらえるならば, 解剖学的な発育発 達，サッカー経験，体力，運動能力，認知能力な どが相互に関連し，それらの要素の相互作用の結 果が全体の発達段階と考えられる。たとえば，ド 
Table 1 Attribute of the participants

\begin{tabular}{c|rccc}
\hline Category & $\begin{array}{r}\text { Age (year) } \\
\text { Mean (S.D) }\end{array}$ & $\begin{array}{c}\text { Soccer experience (year) } \\
\text { Mean (S.D) }\end{array}$ & $\begin{array}{c}\text { Hight (cm) } \\
\text { Mean (S.D) }\end{array}$ & $\begin{array}{c}\text { Weight (kg) } \\
\text { Mean (S.D) }\end{array}$ \\
\hline U-10 & $9.95(0.29)$ & $2.7(1.0)$ & $136.0(4.9)$ & $30.1(3.8)$ \\
U-12 & $12.04(0.25)$ & $5.3(1.9)$ & $146.8(5.5)$ & $36.1(4.5)$ \\
U-14 & $13.85(0.49)$ & $6.3(1.4)$ & $162.9(6.3)$ & $49.4(6.1)$ \\
U-16 & $16.05(0.30)$ & $7.5(1.8)$ & $170.3(4.7)$ & $60.0(5.8)$ \\
\hline
\end{tabular}

レイファス・ドレイファス（1987）の技能獲得の 5 段階では, 初期の段階から認知的な様相を含み ながらそれぞれの段階での特徴を示しており，あ る技能の要素を部分的に獲得しながら最終的に全 体像を作り出すといった考え方をしていない。 ま た，Erricsson（2003）は熟達者のレベルに達する までの過程では，多様な要素が相互に作用するこ とによってその技能の質が段階的に変化していく ことを仮定している.このように人間の運動行動 を多数の要素が非線形に相互作用しながら時間発 展（変化）するシステムとみなすならば，サッカー プレーヤーとしてのそれぞれの発達段階では, 発 達に関連する個々の要素の総和とは異なる様相を 示すことになる。これらのことは，発達に関連す る個々の要素においては個人差が生じた場合でも, 技能獲得過程における各個人の総体としての発達 段階は年齢区分によって大まかにとらえることが できることを示唆するものである.

以上のことから, 本研究ではサッカープレー ヤーとしての発達段階にかかわる要素が複数ある ことを理解したうえで, 年齢による区分によって サッカープレーヤーの発達段階をとらえることと した。また指導場面を考慮した場合にも，サッ カーに打ける実際の指導が年齢区分に基づいて行 われていることから，年齢区分によってサッカー プレーヤーとしての発達段階をとらえることは妥 当であると思われる.

そこで, 本研究ではサッカープレーヤーとして の発達段階を, 年齢区分に基づき $\mathrm{U}$ (アンダー)-10, U-12, U-14, U-16の 4 群に区分した。実際には，例 えば 9 歳のプレーヤーは U-10, U-12, U-14 にも含ま れる.しかし,ここでは, U-10 は 9 歳から 10 歳,
U-12 は 11 歳から 12 歳, U-14 は 13 歳から 14 歳, U-16 は 15 歳から 16 歳を指すものとした。学校で の学年歴との対応でいうと, 標準的に, U-10 は小 学校 3 4 年生, U-12 は小学校 5 6 年生, U-14 は 中学校 $1 \sim 2$ 年生, U-16 は中学校 3 年生〜高校 1 年生に対応していることになる。

\section{2. 実験参加者}

サッカープレーヤーとしての 4 つの発達段階（U10, U-12, U-14, U-16）にある各 20 名の男子プレー ヤーが実験に参加した（Table 1). U-10, U-12, U-14 の実験参加者は， $\mathrm{N}$ 市内にある 3 つのサッカーク ラブに所属し，U-16の実験参加者は同じ市内の私 立高等学校のサッカー部に所属していた。 U-10, U-12, U-14 の実験参加者が所属する各クラブでは 1 週間に 3 日の練習がほぼ 1 年間を通して行われて いる。 また，高等学校のサッカー部は 1 週間に 6 日の練習を基本に 1 年間を通して活動している.

各群に打ける差異を分散分析を用いて検定した ところ, 年齢 $(F(3,76)=1118.05, p<01)$, サッカー 経験年数 $(F(3,76)=33.25, p<.01)$, 身長 $(F(3,76)$ $=166.66, p<.01)$, 体重 $(F(3,76)=137.15, p<.01)$ のいずれにも有意差が認められた。 そして, ホル ムの方法による多重比較を行った結果, すべての 群間に $1 \%$ 水準で有意差が認められた. このこと から，4群間のサッカープレーヤーとしての発達 段階には明確な違いがあるといえる.

さらに，サッカープレーヤーとしての発達段階 の違いによるパス技能発揮の様相を検討するため には, 実験参加者の技能レベルを考慮する必要が ある.それぞれの群の実験参加者のその段階での 相対的技能レベルについては, 本研究の実験参加 
者が同じ市内に属するクラブであり，それぞれの クラブの大会などでの成績に大きな違いはなく， 高等学校のクラブについてもほぼ同じ成績であっ たことから，大きな隔たりはないと考えられる。 また， 3 vs. 1 で発揮されるパス技能は，パスの距離 が短く，パスコースの選択が 2 つかない比較的 簡単な技能であることから, 各群内での実験参加 者の技能レベルの違いが， 3 vs. 1 で発揮されるパス 技能に大きく影響することはないと考えられる。 さらに，各クラブで行われている通常の練習での 指導内容の差の影響も無視できると考えられる.

\section{3. 課題と手順}

課題は 3 人 (攻撃者) で 1 人の相手 (守備者) にボールを奪われないように保持する 3 vs. 1 で あった. 3 vs. 1 はパスの選択肢が $2 つ （$ 味方が 2 人）で守備が 1 人というボール保持課題で，相手 の状況に応じてパスを選択するといったパスの技 能を高めるための最も基本的な課題であり，かつ， パス技能の発揮に多くの要因が関連しないことか ら本研究の課題として用いた。

各群 20 名を 4 人 1 組にした 5 つのグループに分 け, $8 \mathrm{~m} \times 8 \mathrm{~m}$ 四方（以下 $8 \mathrm{~m}$ エリア）, $10 \mathrm{~m} \times 10 \mathrm{~m}$ 四方（以下 $10 \mathrm{~m}$ エリア）, $12 \mathrm{~m} \times 12 \mathrm{~m}$ 四方（以下 $12 \mathrm{~m}$ エリア）の 3 つの異なる広さのエリアでプ レーさせた。 いくつかのサッカー指導書（たとえ ば，Hargreaves, 1990, p. 72; Luxbacher, 1991）に紹介 されている 3 vs. 1 のトレーニング方法でのプレーエ リアが 10 15 ヤード（約 9.2 約 $13.7 \mathrm{~m}$ ）であるこ とから，10m エリアを基準に,それよりも狭いエリ アとして $8 \mathrm{~m}$ エリア，広いエリアとして $12 \mathrm{~m}$ エリ アを設定した。

課題を行うために，まず，4人の中から 1 人を 最初の守備者として任意に決め，パスが次のプ レーヤーに渡らなかったり，エリアからボールが 出たり, 守備者にボールを触れられたりした場合, 最後にプレーした者が次の守備者となった。攻撃 者には 2 回以内のボールタッチでプレーするよう 教示した。また，守備者にボールを奪われたりエ リアの外へボールが出ないようにパスを 15 本通す ことを目標にプレーするようにとの教示を与えた.
さらに守備では，できるだけ積極的にボールを奪 いにいくようにとの教示を与えた。 パスが 15 本を 超えた場合は，そこで一度プレーを止めて任意で 守備者と攻撃者の 1 人を交替させた.

すべての実験参加者が 3 つのエリアでプレーし たが，順序効果を相殺するためにプレーするエリ アの大きさの順番はグループによってすべて変え た．エリアを変えるときは，休息を十分にとって 次のエリアに移行した。また，本研究では 100 本 のパスデー夕を抽出し分析することを目標とした が, U-10, U-12, U-14 では 5 分間プレーを続けても 100 本のパスに到達できない場合もあった。長い 時間プレーを続けることによる疲労がパス技能に 影響することを避けるために，100 本に達する前 に 5 分を経過した場合はそこでプレーを中止した。 その結果，最も少なかったケースはU-10でみられ た 5 分間で 47 本のパスであった。したがって，U16 以外のグループに押いて 100 本ずつのパスを分 析することはできなかったが，統計処理には問題 ないと判断したために 5 分間でのパスの本数を分 析の対象とした。

実験は，6月から 7 月にかけて学校のグラウン ドおよび市内の競技場を使用して実施した。グラ ウンドのサーフェスはいずれも土であり，良好な 状態であった。また，夕方の時間帯で雨や気温が 特別にほかと異なる天候状況で実施したものはな かった。 また，すべてのプレーを競技場のスタン ドあるいはグランド脇建物の 2 階ベランダといっ た高い位置から 1 台のビデオカメラ(DCR-HC96, SONY)で，常に 4 人のプレーヤーが映るようにカ メラアングルを固定し撮影した（Fig. 1)。

\section{4. 分析項目}

3 vs. 1 でのパス技能発揮の様相をパスのパフォー マンス，プレーの早さ，サポートプレーおよびパ スコースの選択の 4 つの観点から分析した。また， パス技能発揮に影響すると考えられる，守備者の ボール保持者に与える空間的負荷の大きさの指標 として，キック時における守備者とボールの間の 距離を計測した。 


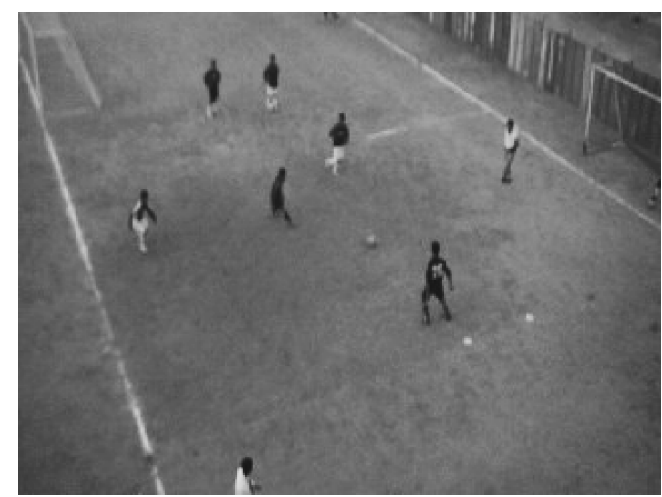

Fig. 1 Experiment situation

1）パスのパフォーマンス

撮影された映像から，3 vs. 1 を実施したグルー プごとにパスの成功率とパスの連続本数の平均を 求めた.

2）プレーの早さ

本研究での 3 vs. 1 では, 1 タッチか 2 タッチで のプレーが求められた. 1 タッチでのプレーはボー ルをコントロールせずにダイレクトにパスするも のであり, ボールに触る前に状況を把握し, パス コースやパスの強さなどを決定しなければならな い.したがって，1タッチプレーの割合が多いと いうことはそれだけ全体的なプレーが早くなる. そこで, 実験参加者ごとに, まず 1 タッチプレー の割合を求めた.

一方, 2 タッチプレーにおいては，ボールコント ロールからキックまでの時間を短くすることによっ て全体のプレーが早くなる．2 タッチプレーでは， 良いボールコントロールからあえて時間を使って, よりパスしやすい状況をつくるプレーもあるが，本 研究での 3 vs. 1 においては，コントロールからキッ クまでの時間が長くなることによって守備者からの プレッシャーが大きくなり, パスコースが限定され やすくなる練習課題である. そこで, 次に, 実験 参加者ごとに, 2 タッチプレーのボールコントロー ルの時点からキックまでの時間を動作時間として, 動作分析ソフト (siliconCOACH Pro, siliconCOACH Ltd.) を使いビデオのコマ数から計測した。

3）サポートプレー

パスに対するサポートの質は，ボール保持者とサ

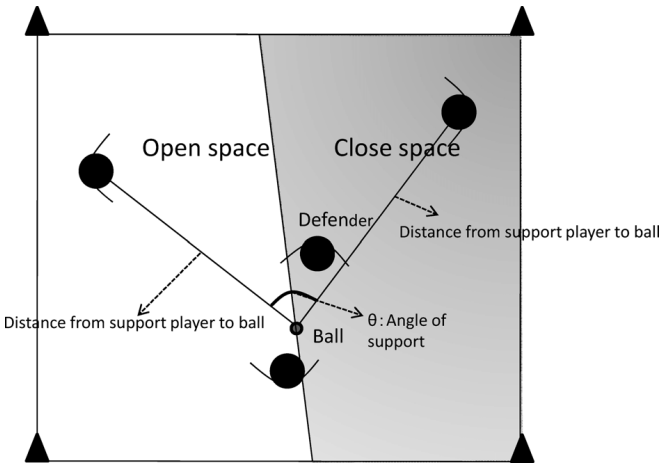

Fig. 2 Diagram of open space, close space, angle of support and distance from support player to ball

ポートプレーヤーの間の角度と距離によって評価さ れる（財団法人日本サッカー協会，2002）。サポー トでは，守備者にボールを奪われないような角度に 位置することが大切であり，ボールの位置を起点と して，それに対する守備者の位置を考慮することに よってサポート位置（角度と距離）が決まる. そこ で，本研究では， $60 \mathrm{~Hz}$ で撮影されたビデオ映像か ら，キック時点での各プレーヤーの両足を結ぶ中心 点とボールの中心点および各プレーエリアの四隅を コントロールポイントとしてデジタイズ (Frame Dias，(株）ディケイエイチ）し，DLT法を用いて 2 次元座標に変換して各プレーヤーとボールの位置関 係を測定した。 キックのインパクトポイントの同定 については，記録データの最初のインパクトが確認 された画像フレームをインパクトポイントとし, イ ンパクトの画像がない場合は，インパクト後の最初 の画像フレームをインパクトポイントとした. そし て，そのインパクトポイントの座標值から求められ るキック時のボールの位置と 2 人のサポートプレー ヤーの位置からそれぞれのサポートの角度 (Fig. 2) を算出した。 また，キックされた時点でのボールの 位置と 2 人のサポートプレーヤーの位置から，ボー ルとサポートとの距離の平均值を算出してサポート の距離の指標とした.

4）パスコース選択の判断

3 vs. 1 ではパスの選択肢は 2 つであり，そのパス選 択を守備者との位置関係で検討するために，キック 時の 2 人のサポートプレーヤーとボール保持者が成 す角度の 2 等分線でスペースをオープンスペースと 

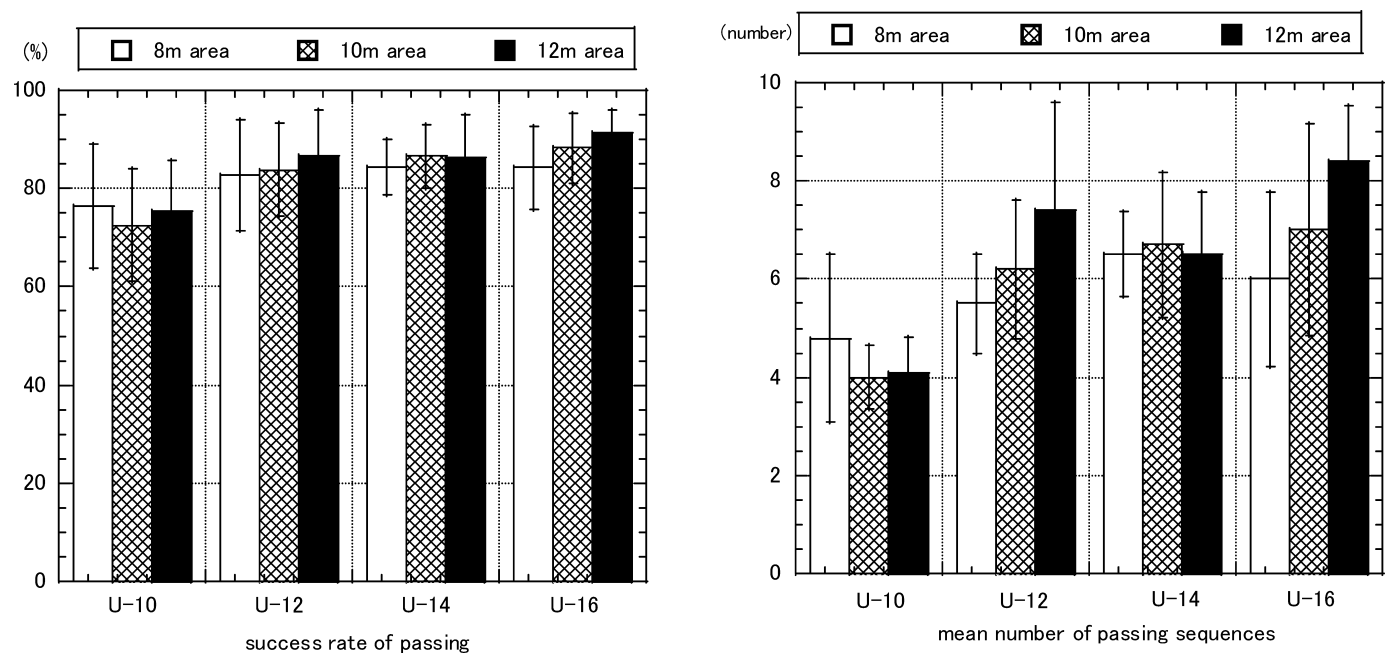

Fig. 3 Passing performance

クローズドスペースに分け (Fig. 2)，そのうち，オー プンスペースへのパスの割合を算出した。すなわち, オープンスペースはパスが出された方向に守備者が 位置していないエリアであり，クローズドスペース はパスが出された方向に守備者がいるエリアである.

5）守備者のボール保持者への空間的負荷

サポートプレーヤーの角度やサポートプレーヤー の距離と同じ方法で，キック時の守備者の位置を デジタイズし, 守備者とボールとの距離を算出し, ボール保持者への空間的負荷の指標とした.

6) 統計処理

分析項目については発達段階 (4 群) $\times$ エリアの 広さ（3 条件）の繰り返しのある二要因分散分析を 行った. 分析項目のうち, サポートの角度, サポー トの距離, パスの連続本数については, 各群でのグ ループごとの平均值を分析した。これら以外の項目 については各実験参加者の平均值を分析した. 分散 分析で有意差が認められた場合には, ホルムの方法 による多重比較を行った。 なお，比率のデー夕は上 限があり正規分布ではないので角変換した数值を用 いた．有意水準はすべての分析で $5 \%$ とした。

\section{3 結果}

1. パスのパフォーマンス

パスのパフォーマンスの結果を Fig. 3 に示した.
パスの成功率については，エリアの大きさの主効 果 $(F(2,152)=1.74)$ は有意ではなかった。しかし, サッカープレーヤーとしての発達段階の主効果 $(F(3,76)=17.95, p<.01)$ が有意であったので，多 重比較をした結果，U-10の成功率が，U-12, U-14, U-16 の成功率よりも有意に低いことが認められた. な技，交互作用 $(F(6,152)=1.34)$ については有意 ではなかった。

パスの平均連続本数についても, エリアの大き さの主効果 $(F(2,32)=2.30)$ は有意ではなかった が，サッカープレーヤーとしての発達段階の主効 果 $(F(3,16)=8.21, p<.01)$ が有意であったので, 多 重比較をした結果, U-10の平均連続本数が, U-12, U-14, U-16 よりも有意に低いことが認められた。な お，交互作用 $(F(6,32)=1.70)$ については有意で はなかった。

\section{2. プレーの早さ}

プレーの早さの結果を Fig. 4 に示した. 1 タッチ プレーの割合については，エリアの大きさの主効 果 $(F(2,152)=6.20, p<.01)$ が有意であった. しか し, 多重比較の結果では水準間での有意差は認め られなかった。 サッカープレーヤーとしての発達 段階の主効果 $(F(3,76)=0.86)$ および交互作用 $(F(6,152)=1.46)$ は有意ではなかった。

2 タッチプレーの動作時間については，交互作用 

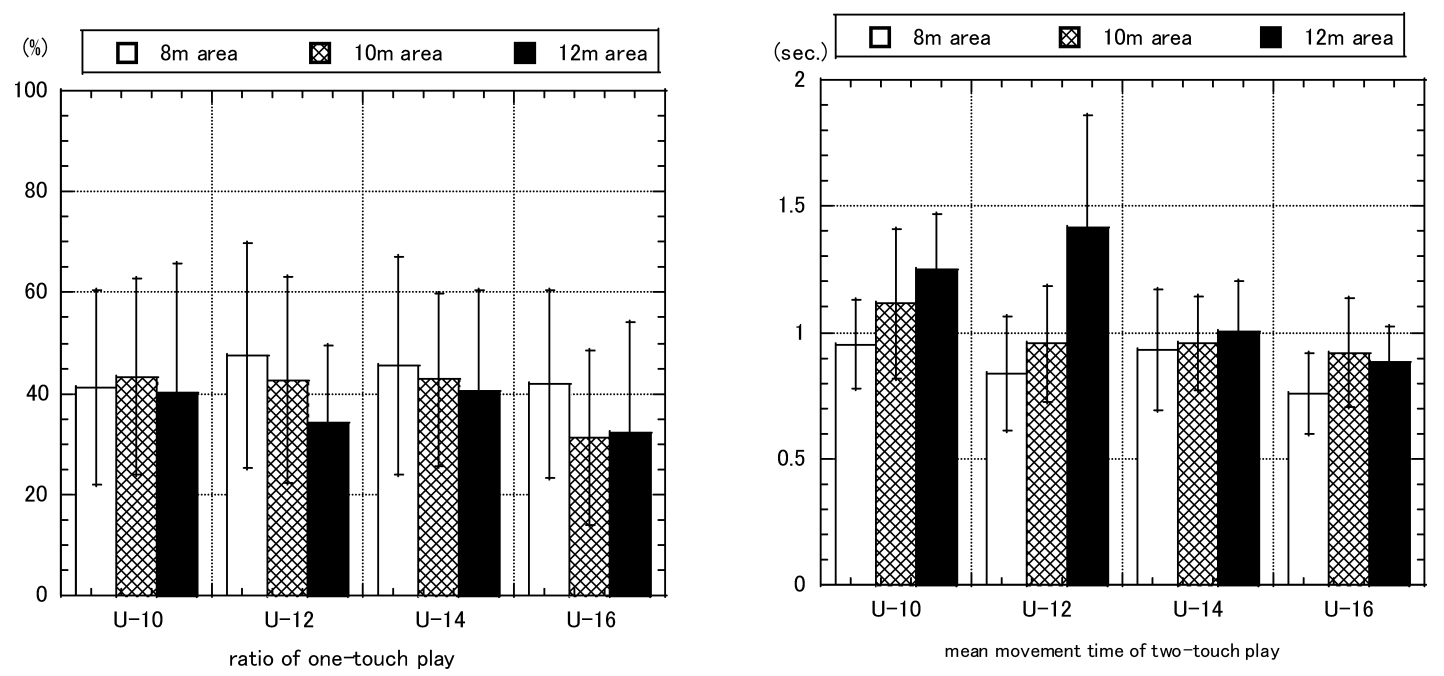

Fig. 4 Speed of passing movement
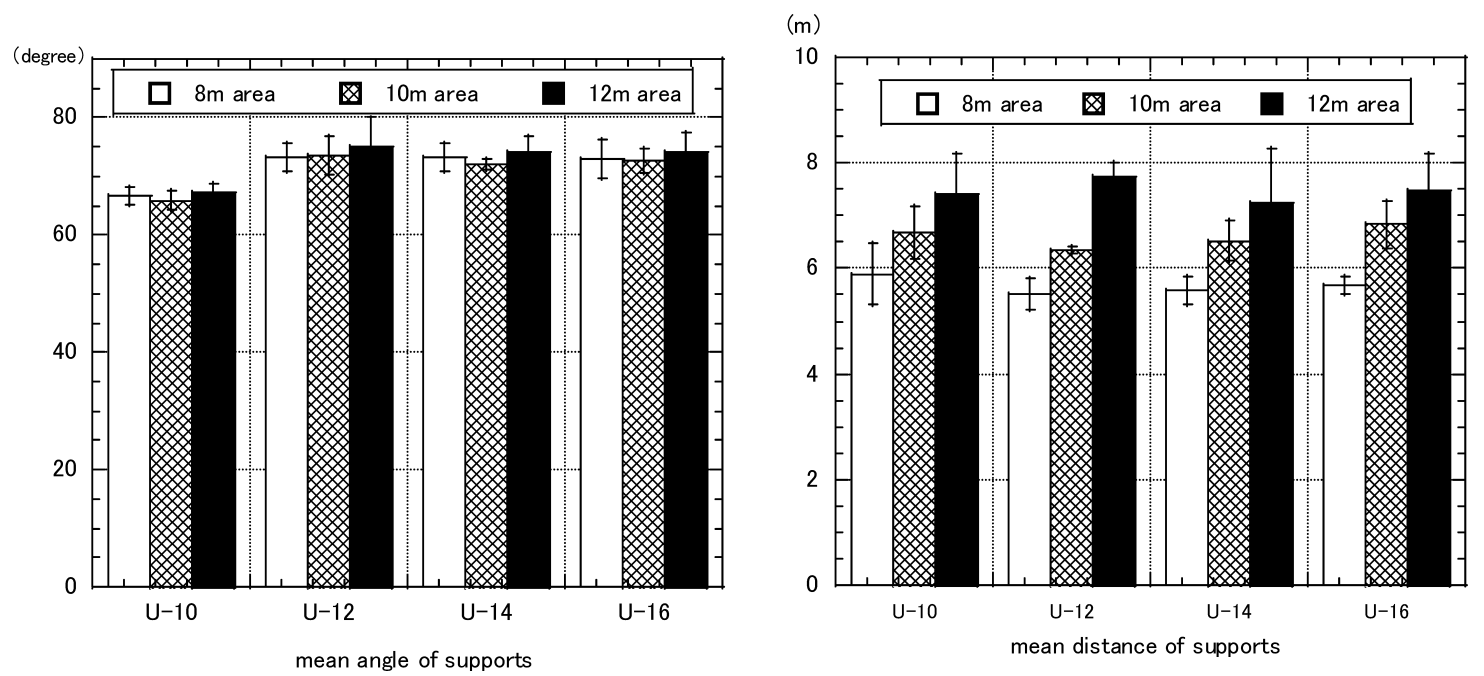

Fig. 5 Angle and distance of supports

が有意であった $(F(6,152)=6.09, p<.01)$. そこで，工 リアの大きさの単純主効果を検定した結果, U-10, U12 では有意差があり, 多重比較の結果, U-10では $8 \mathrm{~m}$ エリアでの動作時間が $10 \mathrm{~m}$ エリア， $12 \mathrm{~m}$ エリア よりも有意に短かった。 また，U-12 では $8 \mathrm{~m}$ エリア, $10 \mathrm{~m}$ エリアでの動作時間が $12 \mathrm{~m}$ エリアよりも有意 に短かった。しかし，U-14,U-16 では有意差はなかっ た. さらに, サッカープレーヤーとしての発達段階 の単純主効果を検定した結果, $8 \mathrm{~m}$ エリアと $12 \mathrm{~m}$ エ リアで有意であった，多重比較の結果， $8 \mathrm{~m}$ エリア では U-10 が U-16よりも有意に動作時間が長かった。
また，有意ではないがそれに極めて近い水準で U-14 が U-16 より長かった. $12 \mathrm{~m}$ エリアでは U-10, U-12 の 動作時間が U-14, U-16よりも有意に長かった。しか し，10m エリアでは有意差はなかった。

3. サポートプレー

サポートの角度と距離に関する結果を Fig. 5 に 示した。 サポートの角度は, エリアの大きさの主 効果 $(F(2,32)=3.88, p<.05)$ が有意であったが, 多重比較の結果では，水準間には有意な差は認め られなかった。 サッカープレーヤーとしての発達 


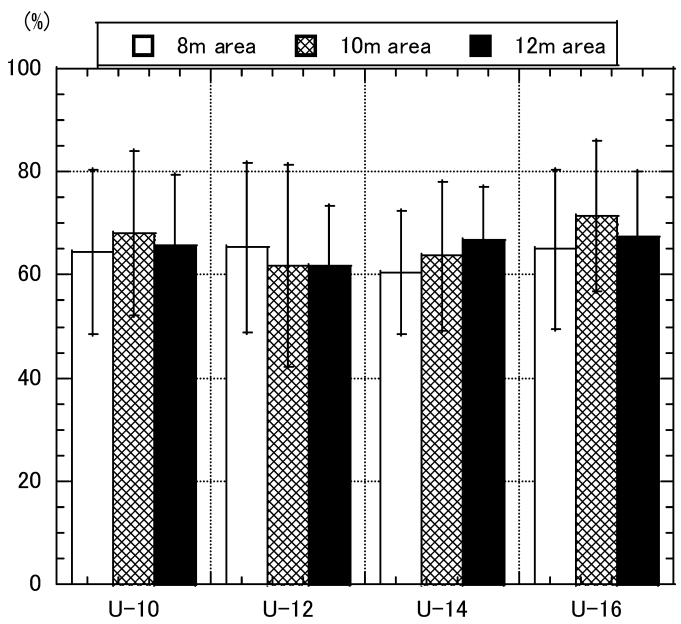

Fig. 6 Rate of passing to the open space

段階の主効果 $(F(3,16)=8.17, \mathrm{p}<.01)$ についても 有意であったので，多重比較をした結果，U-10で のサポートの角度が U-12, U-14, U-16 よりも有意に 小さいことが認められた。しかし，交互作用 $(F(6,32)=0.21)$ は有意ではなかった.

サポートの距離についてはエリアの大きさの主 効果 $(F(2,32)=98.39, p<.01)$ が有意であったので, 多重比較をした結果， $8 \mathrm{~m}$ エリア，10 $\mathrm{m}$ エリア， $12 \mathrm{~m}$ エリアの順でサポートの距離が有意に長いこ とが認められた. サッカープレーヤーとしての発 達段階の主効果 $(F(3,16)=0.23)$ および交互作用 $(F(6,32)=1.14)$ は有意ではなかった。

\section{4. パスコース選択の判断}

オープンサイドへのパスへの割合（Fig. 6）は, すべての条件でほぼ 6 割台であり，エリアの大き さの主効果 $(F(2,152)=0.63)$, サッカープレーヤー としての発達段階の主効果 $(F(3,76)=1.38)$ そし て，交互作用 $(F(6,152)=0.63)$ のいずれも有意で はなかった。

\section{5. 守備者のボール保持者への空間的負荷}

キックした時点でのボールと守備者との距離 （Fig. 7）は，エリアの大きさの主効果 $(F(2,152)=$ 67.11，p<.01）が有意であった。そこで，多重比較 をした結果， $8 \mathrm{~m}$ エリア，10m エリア， $12 \mathrm{~m}$ エリ アの順でボールと守備者との距離が有意に長いこ

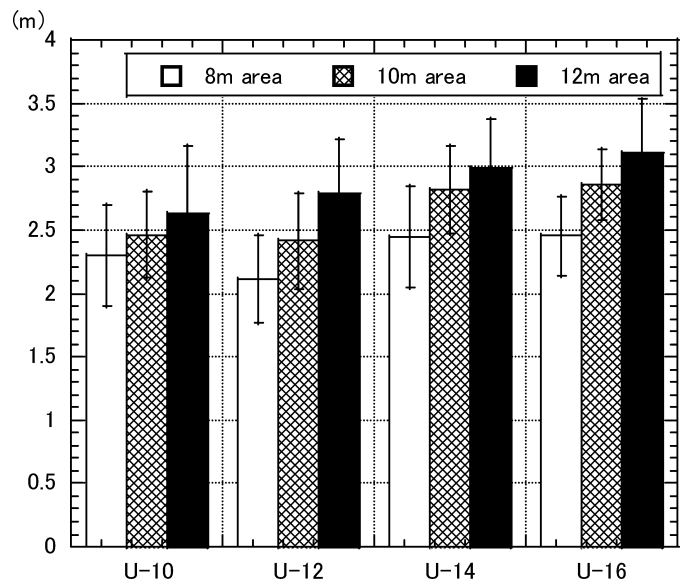

Fig. 7 Distance from the ball to the defender

とが認められた。また，サッカープレーヤーとし ての発達段階の主効果 $(F(3,76)=7.75, p<.01)$ に ついても有意であったので，多重比較をした結果， U-10, U-12 でのボールと守備者の距離が，U-14, U16 よりも有意に短いことが認められた。しかし， 交互作用 $(F(6,152)=1.68)$ は有意ではなかった.

以上の結果の要約を Table 2 にまとめた.

\section{4 考 察}

U-10では，パスの成功率とパスの連続本数と いったパスのパフォーマンスが他の発達段階より 屯劣っているという結果が得られた。この理由の 一つは，サッカーの経験年数が少なく，キックお よびボールコントロールの技能がほかよりも劣っ ていたことであると考えられる。また，ボールを 持たない 2 人のプレーヤーのサポートプレーもパ スのパフォーマンスの低さに関連していると考え られる。すなわち，サポートの角度が，U-10では サッカープレーヤーとしての他の発達段階に比べ て小さく，効果的にサポートができていなかった ことが示唆される。瀧井（2003）はサッカーの ゲームパフォーマンスの発達位相の第 1 位相の特 徵を「…チームワークあるいは役割分担がほとん ど存在しなかった状況」としており，サッカー経 験の少ない U-10 の実験参加者もこの段階であると 考えられる。また，8mエリアでのパスの成功率 
Table 2 Summary of ANOVA results

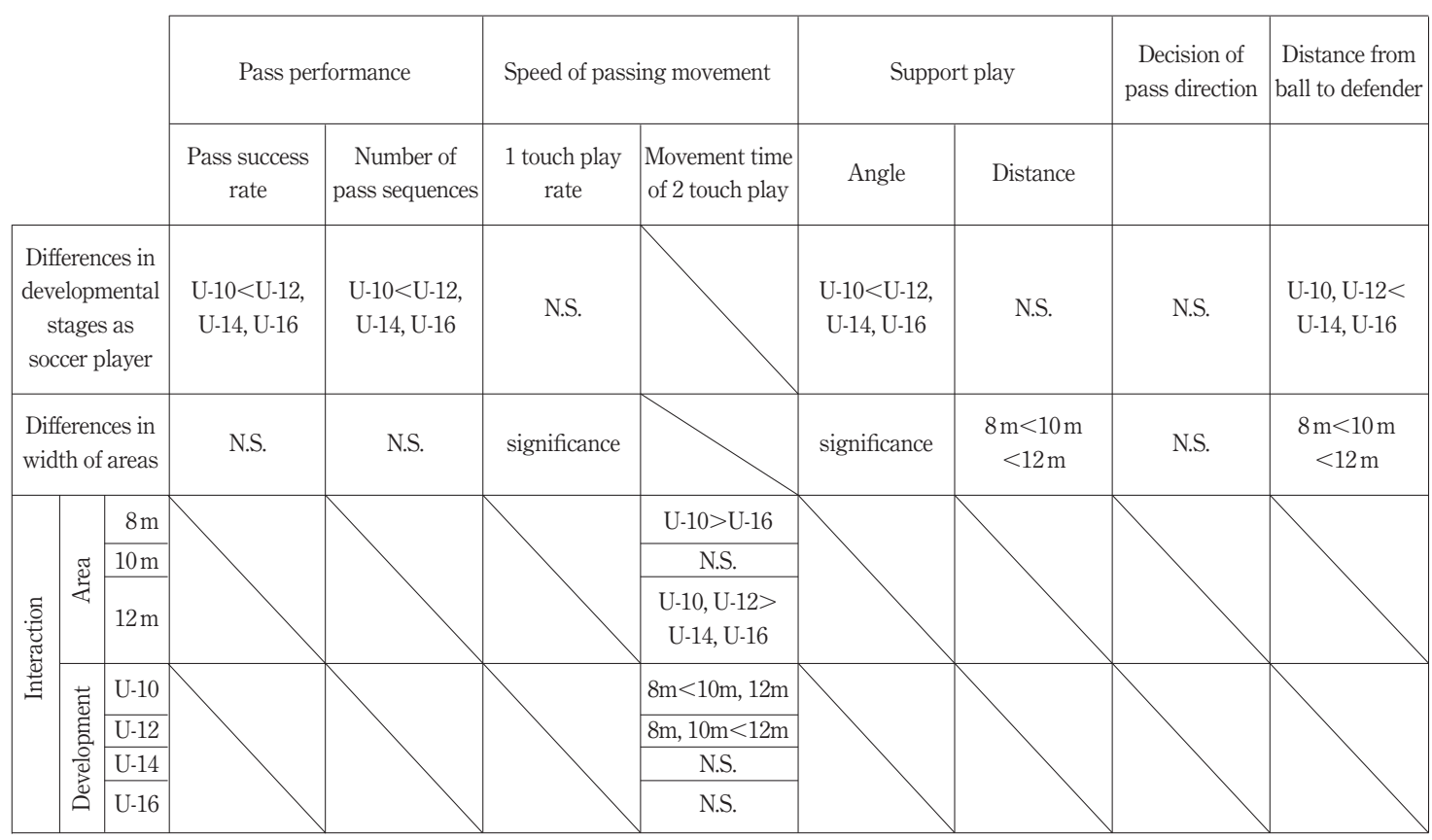

は変わらないが, 2 タッチプレーの動作時間は他 のエリアよりも早くなった。 つまり, $8 \mathrm{~m}$ エリアで は, パフォーマンスを落とさないために, ボール コントロールからキックまでの時間を短くすると いったプレーを強制する力が働くと考えられる. さらに, 2 タッチプレーの動作時間が $10 \mathrm{~m}$ エリア, $12 \mathrm{~m}$ エリアで長くなった理由として, サポートの 距離が長くなり, 長い距離のパスをするために大 きなキック動作をしなければならなかったという ことも考えられる.したがって，この年代ではエ リアを広くすることで，プレーがしやすくなると は限らず，また，エリアを狭くすることによって， 持っている技能を素早く発揮することを強制する 場合があることを示唆するものである．財団法人 日本サッカー協会 (2003c) では, 発達段階に応じ たゲーム環境の重要性を指摘し，U-10ではピッチ のサイズを狭く設定した 8 対 8 のゲーム形式を推 奨しているが, 本研究の結果は, それに実証的基 礎を与え, 発達段階に応じた適切なプレーエリア の選択が指導場面では重要であることを示唆する むのである.

U-12では, 守備者とボールの距離が U-10 と変わ らなかったが，パスのパフォーマンスは U-10より
優れていた。これは，キックやコントロールの技 能が U-10よりも優れており，またサポートプレー が効果的になされていたことが一つの要因である と考えられる. また，U-12でのパスのパフォーマ ンスやサポートプレーはサッカープレーヤーとし ての発達段階が上である U-14, U-16 と違いがなかっ た.このことから， 3 vs. 1 で必要な基本的なパス技 能やサポートプレーは U-10 から U-12 の段階で, あ る程度習得されることが示唆される。

次に, U-12 でのプレーの早さをみると，2 夕ッ チプレーの動作時間が U-10 と同様に $12 \mathrm{~m}$ エリア で，U-14, U-16よりも長かった。 さらに，統計的な 有意差は認められなかったが, 1 タッチプレーの 割合は $12 \mathrm{~m}$ エリアで $8 \mathrm{~m}$ エリアよりも值が低かっ た. したがって, U-12 では $12 \mathrm{~m}$ エリアでのプレー が他の条件よりも遅いといえる. 2 タッチプレー の動作時間が長くなる要因の 1 つとして, パス コースを判断するために要する時間が挙げられる. すなわち, $8 \mathrm{~m}$ エリアや $10 \mathrm{~m}$ エリアではパスコー スの選択に時間をかけずに，あるいは，時間をか けることができずにプレーしていたが， $12 \mathrm{~m}$ エリ アになって守備者からの空間的負荷が小さくなっ たことにより, また, サポートの距離が長くなっ 
たことにより，ボールをコントロールしてから時 間をかけてパスコースを選択するプレーが多くなっ てしまったのではないかと推察される。しかしな がら，オープンかクローズかのパス選択の比率は エリアの大きさにかかわらず同じであり，判断に 時間をかけたことによって判断が正しくなったと はいえなかった。 したがって, 状況を素早く判断 しプレーすることが求められるサッカーではこの ような遅いプレーは好ましいものではなく， $12 \mathrm{~m}$ エリアは U-10 だけでなく， U-12 にとっても 3 vs. 1 でのより良いプレー選択を強制しない環境である と考えられる．つまり， 3 vs. 1 において広すぎるプ レーのエリアは U-10, U-12 のプレーヤーに楽な選 択をもたらし，安易なパス動作が出現しやすいと 考えられる.

U-14 ではパスのパフォーマンスについて U-12, U16 と有意な差はなかった。しかしながら，U-14の 2 タッチプレーの動作時間は $12 \mathrm{~m}$ エリアでは U-16 とともに U-10, U-12 よりも短かったことから, U10, U-12 とは異なるパス技能が発揮されていると考 えられる. また, U-16 と比較して, 守備者とボー ル保持者の間の距離が変わらないことから, 身体 が小さい U-14 では守備者からの空間的負荷は U-16 よりも小さいと思われる。そのためボール保持者 は多少の時間的余裕を持つことができたために, 有意ではなかったがそれに極めて近い水準で $8 \mathrm{~m}$ エリアでの 2 タッチの動作時間が U-16 よりも長く なったと考えられる.つまり, U-14 では 3 vs. 1 で 発揮されるパス技能は U-10, U-12よりも向上して いるが，U-16よりも劣る，いわゆる移行期にある ことを示唆するものである。したがって，U-14で は， $8 \mathrm{~m}$ などの狭いエリアでの練習を中心にして パス技能を向上させることが有効であると考えら れる。

同じように, U-16ではパスのパフォーマンスが U-12, U-14 と違いはなかった. しかし，8mエリア でのプレーの早さが U-16 の一つの特徵である. $8 \mathrm{~m}$ エリアではボール保持者と守備者との距離が U-14 之同様に他の発達段階よりも狭く, しかも身体の 大きさが U-14よりも大きいことから, 守備者から の空間的負荷がすべての発達段階の中で最も高
かったと考えられる。それにもかからず，パスの パフォーマンスが U-12, U-14 に劣っていなかった. 守備者からのプレッシャーが大きい中で, 早く正 確にプレーすることがサッカーでは求められる. したがって，U-14 から U-16の段階では 3 vs. 1 で の難易度を高めるためにエリアを狭くしていくこ とは効果的であると考えられる。

\section{5 ま と め}

本研究では, サッカープレーヤーとしての発達 段階が異なる男子プレーヤーを対象に，3 人の攻 撃者に 1 人の守備者が入る 3 vs. 1 ボール保持課題 で，生体の制約であるサッカープレーヤーとして の発達段階と, 課題の制約であるエリアの大きさ がパス技能発揮の様相に与える影響を明らかにし， より効果的なパス技能の練習環境を探索的に検討 することを目的とした。

その結果, 3 vs. 1 において $12 \mathrm{~m}$ エリアのプレー エリアは U-10, U-12 のプレーヤーにとっては広す ぎ，楽な選択をもたらし，安易なパス動作が出現 しやすいと考えられた。 また，U-14 から U-16 の段 階では, 3 vs. 1 での難易度を高めるためには $8 \mathrm{~m}$ エリアまで狭くしていくことは効果的であると考 えられた。これらのことは, サッカープレーヤー としての発達段階に応じた適切なプレーエリアの 選択が指導場面では重要になることを示唆するも のであった。

\section{謝辞}

本研究は, 筑波大学大学院人間総合科学研究科 朝岡正雄教授，山田幸雄教授，大西武教授，小池 関也准教授より多くの御指導を賜りました。 心よ り感謝申し上げます。

\section{文献}

Araújo, D., Davids, K., Bennett, S.J., Button, C. , and Chapman, G. (2005) Emergence of sport skills under constraints. In: Williams, A. M. and Hodges, N. J. (Eds.) Skill acquisition in sport: Research, theory and practice. Routledge: London, 
pp. 409-433.

Davids, K., Button, C., and Bennett, S. (2008) Dynamics of skill acquisition: A constraints-led approach. Human Kinetics: Champaign.

ドレイファス・ドレイファス:椋田直子訳（1987）純粋人 工知能批判. アスキー：東京.〈Dreyfus, H.L. and Dreyfus, S.E. (1986) Mind over machine: The power of human intuition and expertise in the era of the computer. Free Press: New York. $>$

Ericsson, K.A. (2003) Development of elite performance and deliberate practice: An update from perspective of the expert performance approach. In: Starkes, J. L. and Erricsson, K.A. (Eds.) Expert performance in sports: Advances in research on sport expertise. Human Kinetics: Champaign, pp. 49-87.

Hargreaves, A. (1990) Skills and strategies for coaching soccer. Leisure Press: Champaign.

Luxbacher, J. A. (1991) Teaching soccer: Steps to success. Leisure Press: Champaign, p. 118.

中山雅雄（2004）（財）日本サッカー協会のコーチング コンセプトの理論的, 実験的研究の観点からの検討. スポーツコーチング研究, 3(1), (http://www.taiiku.tsukuba.ac.jp/sc/3_1/01/index.html).

Nakayama, M. (2008) The effects of play area size as task constraints on soccer pass skills. Football Science, 5: 1-6.

中山雅雄・浅井武・田嶋幸三（2007）サッカーのパス技 能と練習課題の制約との関連. 体育学研究, 52: 419430 .

Newell, K.M. (1986) Constraints on the development of coordination. In: Wade, M. G. and Whiting, H. T. A. (Eds.) Motor development in children: Aspects of coordination and control. Martinus Nijhoff: Dordrecht, pp. 341-360.

瀧井敏郎（2003）サッカーにおける戦術学習の視点に基 づくゲームパフォーマンスの評価. スポーツ運動学研 究, 16: 37-48.
多和健雄 - 長沼 健 - 永嶋正俊 - 長池 実 - 鈴木嘉 三・畑山 正（1978）現代スポーツコーチ全集サッ カーのコーチング (4 版). 大修館書店 : 東京.

Van Lingen, B. (1997) Coaching soccer: The official coaching book of the Dutch soccer association. Reedswain Videos and Books: Pennsylvania.

Wade, A. (1978) The F.A. guide to teaching football. William Heinemann Ltd: London.

Williams, A.M. (2003) Learning football skills effectively: Challenging tradition. Insight The FA Coaches Association Journal, 6(2): 37-39.

財団法人日本サッカー協会技術委員会（2002）サッカー 指導教本フィールドプレーヤー編. 財団法人日本サッ カ一協会 : 東京, p. 26.

財団法人日本サッカー協会技術委員会テクニカルハウス 編（2003a）JFA キッズ（U-6）指導ガイドライン. 財 団法人日本サッカー協会 : 東京.

財団法人日本サッカー協会技術委員会テクニカルハウス 編（2003b）JFA キッズ（U-8）指導ガイドライン. 財 団法人日本サッカー協会 : 東京.

財団法人日本サッカー協会技術委員会テクニカルハウス 編（2003c）JFA キッズ（U-10）指導ガイドライン. 財 団法人日本サッカー協会：東京.

財団法人日本サッカー協会技術委員会テクニカルハウス 編（2004）JFA 2007 U-16 指導指針. 財団法人日本サッ カ一協会 : 東京.

財団法人日本サッカー協会技術委員会テクニカルハウス 編（2007a）JFA 2007 U-14 指導指針. 財団法人日本 サッカー協会：東京.

財団法人日本サッカー協会技術委員会テクニカルハウス 編（2007b）JFA 2007 U-12 指導指針. 財団法人日本 サッカー協会 : 東京.

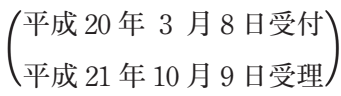

